\title{
Storage stability of soy protein isolate films incorporated with mango kernel extract at different temperature
}

\begin{abstract}
This research investigated the storage stability of antioxidant films made from waste and byproducts which are soy protein isolate (SPI) and mango kernel extract (MKE) stored at room temperature $\left(25^{\circ} \mathrm{C}\right)$, refrigeration temperature $\left(4^{\circ} \mathrm{C}\right)$ and frozen temperature $\left(-18^{\circ} \mathrm{C}\right)$ for 90 days. The thickness of the films was maintained from 0.050 to $0.058 \mathrm{~mm}$ until the 90th day. The colour properties of SPI films incorporated with MKE (SPI + MKE) were generally not significantly affected by time and temperature except for the $b$ value. All the films turned darker over the storage time. There was no dominant factor between temperature and time for the mechanical properties; all the films showed an increase in tensile strength and Young's modulus, and a decrease in elongation. The antioxidant activity of the films was determined by the total phenolic content and radical scavenging activity of DPPH and ABTS. SPI + MKE film at $25{ }^{\circ} \mathrm{C}$ showed the highest antioxidant activity as compared to films stored at $4{ }^{\circ} \mathrm{C}$ and $-18{ }^{\circ} \mathrm{C}$ in all the analyses, with the result being significant in DPPH and ABTS analyses. The film stored at $25{ }^{\circ} \mathrm{C}$ showed 26 to $50 \%$ higher $(\mathrm{p}>0.05)$ TPC than films stored at $4{ }^{\circ} \mathrm{C}$ and $-18^{\circ} \mathrm{C}$, respectively and had the highest antioxidant activity $(54 \%)$ in ABTS analysis $(\mathrm{p}<$ $0.05)$. SPI + MKE film stored at $25^{\circ} \mathrm{C}$ also showed only $1 \%$ depreciation of radical scavenging activity (RSA) throughout the storage time. The highest decrease (4\%) in antioxidant activity was recorded for SPI $+\mathrm{MKE}$ film stored at $-18{ }^{\circ} \mathrm{C}$, although it was considered very low. This shows that the antioxidant activity of the films is stable for 90 days of storage.
\end{abstract}

Keyword: Mango kernel extract; Soy protein isolate; Storage stability; Active packaging; Antioxidant film 